\title{
Environmental effects on zooplankton abundance on a sub-Arctic shelf off northern Norway
}

\author{
K. Eiane $\mathrm{e}^{1, *}$, M. Espinasse ${ }^{1}$, B. Espinasse ${ }^{2}$ \\ ${ }^{1}$ Nord University, PO Box 1490, 8049 Bodø, Norway \\ ${ }^{2}$ Department of Earth, Ocean and Atmospheric Sciences, University of British Columbia, Vancouver, BC, V6T1Z4, Canada
}

\begin{abstract}
We studied the abundance of common zooplankton on 8 dates and at 5 locations on the shelf off the Lofoten Islands, northern Norway, between September 2013 and August 2014. We tested for relationships between environmental variability and abundances. We found that, of 17 zooplankton taxa or groups for which we recorded abundances, 4 omnivorous or carnivorous groups persistently differed in abundance between stations. This difference probably reflected relatively deep centres of distribution in the water column, and abundances of these species were positively associated with bottom depth. In 10 taxa or groups, abundance correlated with sampling date or temperature, salinity, or fluorescence, but generally not with bottom depth. Most of these taxa were consumers on low trophic levels, with a vertical distribution often associated with near-surface waters. In the remaining taxa or groups, no association between abundance and the environment or with time of sampling was established. Our results suggest that on-shelf abundances of zooplankton with intermediate-to-deep vertical distribution patterns are mainly limited by bathymetry, while abundance variations in zooplankton with a predominately near-surface distribution are driven by intra-annual environmental variability.
\end{abstract}

KEY WORDS: Plankton ecology $\cdot$ Sub-polar $\cdot$ Hydrography $\cdot$ Seasonality

\section{INTRODUCTION}

Seasonal variability and location differences in the abundance of high-latitude coastal marine zooplankton can span several orders of magnitude (e.g. Østvedt 1955, Eiane et al. 2002, Daase et al. 2007). Such fluctuations likely reflect effects of variability in the environment on the gain and loss processes acting in populations (Hirche et al. 2001, Hays et al. 2005, Willis et al. 2008, Skreslet et al. 2015). The mechanisms linking environmental variability with variability in zooplankton populations are only partly understood (Arashkevich et al. 2002, Astthorsson \& Gislason 2003, Walkusz et al. 2009). This is unfortunate as marine zooplankton provides important trophic linking between the microalgae community and higher trophic level animals, thereby propagating new biological production (Banse 1995, Falk-

\footnotetext{
*Corresponding author: ketil.eiane@nord.no
}

Petersen et al. 2000), but likely also environmental variability, to higher trophic levels (Richardson \& Schoeman 2004, Buttay et al. 2016, Suchy et al. 2016).

On the larger spatial scales $\left(>10^{3} \mathrm{~km}\right)$, characteristic of oceanic ecosystems, variability in zooplankton abundance appear largely driven by climate variability (Fromentin \& Planque 1996, Chiba \& Saino 2003, Beaugrand 2012). On mesoscale $\left(<10^{2} \mathrm{~km}\right)$, which is more characteristic of many coastal ecosystems (Vilar et al. 2003, Vogedes et al. 2014), the picture is less clear. This is because mesoscale heterogeneity in food supply (Young et al. 2009, Suchy et al. 2016) or predation pressure (Bagøien et al. 2001, Eiane et al. 2002, Ohman \& Hsieh 2008) generate variability in zooplankton abundance, but zooplankton distribution also depends on advection and bathymetry (Tremblay \& Roff 1983, Daase \& Eiane 2007, Walkusz et al. 2009). In coastal waters, mesoscale spatial hetero-

() The authors 2018. Open Access under Creative Commons by Attribution Licence. Use, distribution and reproduction are unrestricted. Authors and original publication must be credited. 
geneity in the zooplankton often reflects topographic steering of on-shelf and coastal current systems (Daase \& Eiane 2007, Munk et al. 2015, Skreslet et al. 2015). Thus, zooplankton aggregations can occur in association with the complex hydrography typically forming over shelf breaks (Barange 1994) and in canyons (Macquart-Moulin \& Patriti 1996), for example as a combined effect of local upwelling and vertical behaviour (Genin 2004). This suggests that species-specific differences in habitat choice (Conover \& Huntley 1991, Bagøien et al. 2001) or diel and seasonal vertical behaviour strategies (Bandara et al. 2018 and references therein) in concert with local hydrographical variability may lead to differences between zooplankton species in their tendency to passively form aggregations.

Here we address the hypothesis that topographically driven hydrographical differences on the shelf contribute to maintaining ecologically relevant mesoscale structures (Genin 2004) by providing new information on the seasonal variation in zooplankton on the northern Norwegian shelf (see Fig. 1). This shelf sustains high planktonic primary and secondary production in spring and summer (Dalpadado 2006) and is a major spawning and larval drift area for the migrating Northeast Arctic cod stock (Ottersen et al. 2014). Although frequently studied during the spawning period in spring (e.g. Sundby 2000, Brander et al. 2001), there is little available information on the biophysical variability in this area at other times of the year (Dalpadado 2006, Zhou et al. 2009). We study relevant variability by quantifying hydrography and zooplankton abundance at several locations on the shelf and at different times of year. By testing for relationships between the seasonal zooplankton variability both with environmental variability occurring over a year and between different locations with varying depth and surrounding bottom topography, we identify to which extent variability in selected taxa or groups of zooplankton varied primarily with the environmental changes occurring over a year or were more location specific.

\section{MATERIALS AND METHODS}

\section{Study area}

We focused our study on the continental shelf north of the Lofoten Islands, northern Norway $\left(69^{\circ} \mathrm{N}\right.$; $14.5^{\circ} \mathrm{E}$ ). Here the shelf is relatively narrow (ca. $25 \mathrm{~km}$ ) and characterized by a complex topography with several sub-surface canyons (Fig. 1). The circu-

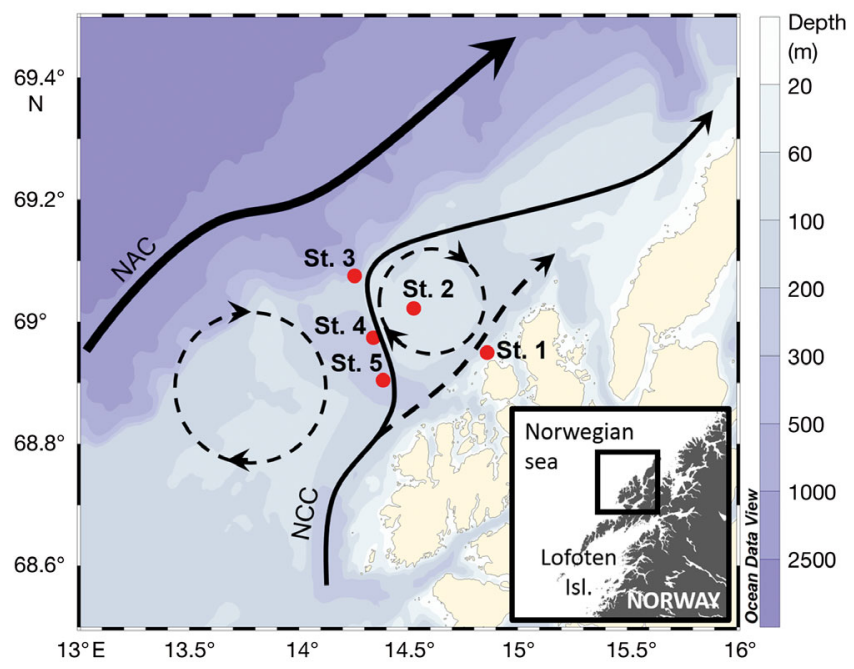

Fig. 1. Location of the field stations (Stns 1-5), as well as a schematic representation of the dominant circulation system based on modelled velocity fields from March to August 2014. More or less permanent features i.e. the North Atlantic current (NAC) and the Norwegian Coastal Current (NCC) are indicated by solid lines. More sporadic patterns are indicated by dashed lines

lation system on this part of the shelf is dominated by 2 major northward-flowing currents, the North Atlantic Current (NAC) and the Norwegian Coastal Current (NCC; Sætre 1999, Mitchelson-Jacob \& Sundby 2001). The NCC is a relatively low-salinity current on the Norwegian shelf that enters the study area from the south (Fig. 1). The more saline NAC flows over the continental shelf slope, offshore of the NCC (Gascard et al. 2004) and, through interaction with the $\mathrm{NCC}$, is believed to produce significant fluxes of oceanic water masses and associated biota onto the shelf in spring and summer (Slagstad \& Tande 2007, Samuelsen et al. 2009, Opdal \& Vikebø 2016). The spatial and temporal variability in hydrography and plankton in this area, therefore, may partly reflect advection from both southern and offshore sources.

\section{Field collections}

We conducted field collections of hydrography and plankton at 5 stations (Stns 1 to 5, Fig. 1), on 8 occasions from September 2013 to August 2014 during cruises with available local fishing vessels. Due to weather conditions and time constraints, not all stations could be sampled on all dates (Table 1). At each station, we profiled the water column hydrography by a CTD fitted with a Turner design fluorometer (model SD204, SAIV Environmental Sensors \& Sys- 
Table 1. Overview of sampling dates, stations (Stns 1-5) and depth intervals sampled in the present study (see Fig. 1 for geographic location of stations)

\begin{tabular}{|c|c|c|c|c|c|c|}
\hline Sampling date & Vessel & $\begin{array}{c}\text { Stn } 1 \\
\text { Near-shore } \\
0-33 \mathrm{~m}\end{array}$ & $\begin{array}{c}\text { Stn } 2 \\
\text { Bank } \\
0-75 \mathrm{~m}\end{array}$ & $\begin{array}{c}\text { Stn 3 } \\
\text { Shelf slope } \\
0-50,50-175,175-330 \mathrm{~m}\end{array}$ & $\begin{array}{c}\text { Stn } 4 \\
\text { Outer trough } \\
0-50,50-200 \mathrm{~m}\end{array}$ & $\begin{array}{c}\text { Stn } 5 \\
\text { Inner trough } \\
0-50,50-270 \mathrm{~m}\end{array}$ \\
\hline 10 Sep 2013 & F/V 'Brutus' & & $\mathrm{x}$ & $\mathrm{x}$ & $\mathrm{x}$ & \\
\hline 23 Oct 2013 & F/V 'Kloegga' & $\mathrm{x}$ & $\mathrm{x}$ & & $\mathrm{x}$ & $\mathrm{x}$ \\
\hline 22 Jan 2014 & F/V 'Kloegga' & $\mathrm{x}$ & $\mathrm{x}$ & $\mathrm{x}$ & $\mathrm{x}$ & $\mathrm{x}$ \\
\hline 1 Apr 2014 & F/V 'Mea' & $\mathrm{x}$ & $\mathrm{x}$ & & $\mathrm{x}$ & $\mathrm{x}$ \\
\hline 1 May 2014 & F/V 'Skårungen' & $\mathrm{x}$ & $\mathrm{x}$ & & $\mathrm{x}$ & $\mathrm{x}$ \\
\hline 20 May 2014 & F/V 'Mea' & $\mathrm{x}$ & $\mathrm{x}$ & $x^{a}$ & $\mathrm{x}$ & $\mathrm{x}$ \\
\hline 22 Jul 2014 & F/V 'Mea' & $\mathrm{x}$ & $\mathrm{x}$ & $\mathrm{x}$ & $\mathrm{x}$ & $\mathrm{x}$ \\
\hline 27 Aug 2014 & F/V 'Mea' & $\mathrm{x}$ & $\mathrm{x}$ & $\mathrm{x}$ & $\mathrm{x}$ & $\mathrm{x}$ \\
\hline
\end{tabular}

tems). Zooplankton was collected by vertical hauls with a WP-2 plankton net (area $=0.25 \mathrm{~m}^{2}$, mesh size $=180 \mu \mathrm{m}$, towing speed ca. $0.5 \mathrm{~m} \mathrm{~s}^{-1}$ ) from close to bottom to the surface. At the near-shore and bank sampling locations (Stns 1 and 2), the bottom depths were ca. 30 and $75 \mathrm{~m}$, respectively, and these stations were sampled by one depth-integrating net haul. Stns 3-5 were deeper and therefore net sampling was conducted in several depth bins in these stations (Table 1) by the use of a messenger-operated closing device fitted to the net (Hydro-Bios). Zooplankton samples were fixed in a borax-buffered $4 \%$ formaldehyde-in-seawater solution and brought to the lab for counting. Samples were split 2 to 7 times with a Motoda type box splitter (Motoda 1985) depending on zooplankton concentration, and all organisms in one fraction were assigned to taxa or group and counted (average individuals counted per sample $=$ 384). Nauplii were not assigned to taxa but lumped into one category. Abundance (ind. $\mathrm{m}^{-2}$ ) was estimated assuming $100 \%$ filtering efficiency of the net. During periods of high biomass of algae or other organisms (e.g. gelatinous organisms), plankton nets may clog and decrease in efficiency, thus our data may reflect a lower estimate during such periods. In the present study, we have focussed on the holoplanktonic fraction of the zooplankton. A detailed account of the meroplankton fraction of the zooplankton community collected during this field investigation is provided by Silberberger et al. (2016).

\section{Modelling of current system}

To be able to better relate observations of zooplankton community to the prevailing circulation system in the study area, we simulated velocity fields in
March and August 2014 using the ocean modelling system NorKyst-800 (Albretsen et al. 2011). NorKyst800 is based on the public domain Regional Ocean Modeling System (ROMS), which is a 3D free-surface, hydrostatic, primitive equation ocean model using terrain-following s-coordinates in the vertical dimension (Shchepetkin \& McWilliams 2005, Haidvogel et al. 2008). We relied on a model setup based on a $50 \mathrm{~m}$ resolution bathymetry provided by the Norwegian Mapping Authority Hydrographic Service. Lateral boundary conditions were taken from the Norwegian Meteorological Institute's (MET) Nordic4km model while the atmospheric forcing was based on MET's weatherforecast modelHIRLAM10km (http://thredds. met.no/thredds/fou-hi/nordic4km.html). Tidal forces were modelled based on a global inverse barotropic model of ocean tides (TPXO7.2, http://volkov.oce. orst.edu/tides/TPXO7.2.html) and fresh water runoff was implemented as modelled by the Norwegian Water Resources and Energy Directorate (www.nve.no). The Norkyst-800 model has been used with success in other recent studies showing relatively good agreement with field data (e.g. Myksvoll et al. 2014, Skarðhamar et al. 2015). The model domain covered the whole Norwegian Sea from $55.8^{\circ}$ to $73.8^{\circ} \mathrm{N}$ and $-0.5^{\circ}$ to $34.8^{\circ} \mathrm{E}$, with $820 \times 2420$ horizontal grid cells, each $800 \times 800 \mathrm{~m}$ in size.

\section{Data analysis}

Differences in zooplankton abundance between the 5 sampling stations were quantified as averaged abundances (ind. $\mathrm{m}^{-2}$ ) for each zooplankton group per station. As an initial test of how zooplankton abundance varied with bathymetry and season, we lumped log-transformed abundance data for all taxa or groups 
into 2 levels of 1 factor related to bottom depth ('shallow' comprising Stns 1 and 2, and 'deep' comprising Stns 3 to 5), and 3 levels of 1 factor reflecting seasonality in water column temperature and fluorescence (autumn: September and October, 2013; winter: January and April, 2014; summer: May through August, 2014). We modelled abundance effects of either factor in all taxa or groups by starting with 2-way ANOVA models and selected minimal adequate models of the aggregated relationships by including only significant ( $p<0.05)$ factors. We inspected residuals by standard diagnostic plots and tested for normality by the Shapiro-Wilk test. The F-test in ANOVA is relatively robust to deviations from normality (e.g. Tiku 1971), thus we accepted minor deviations from normality (but never $\mathrm{p}<0.01$ ) as long as residuals were otherwise reasonably well-behaved. However, we note that as the number of samples here are quite low, results should be interpreted with care.

To further elaborate on the specific mechanisms underlying the aggregated relationships, we tested for differences between all stations using the KruskalWallis rank test, as station-specific abundance data were generally not normally distributed. To account for the variability in the different zooplankton groups between sampling dates, we averaged abundances (ind. $\mathrm{m}^{-2}$ ) across stations for each sampling date. Abundance data were $\log (x+1)$ transformed to homogenize variability and taking zero-values into account, and averages were plotted against time and visually inspected for seasonal maxima and minima. To test for relationships between environmental variability and zooplankton abundance, we correlated time and location-specific abundance estimates (ind. $\mathrm{m}^{-2}$ ) of each zooplankton group or taxa against temperature $\left({ }^{\circ} \mathrm{C}\right)$, salinity, and fluorescence (a proxy for algal biomass) in 0-50 m (0-30 m in Stn 1), day-ofyear number of sampling (a proxy for seasonality), and bottom depth. As data were generally not normally distributed, we used the non-parametric Kendall's rank correlation $(\tau)$.

We quantified temporal variability in vertical habitat use from the depth-stratified abundance estimates obtained from the 3 deep stations (Stns 3-5) by applying the vertical distribution index $(V)$, defined by Bandara et al. (2016) as

$$
V=\frac{N_{0-50}-N_{>50}}{N_{0-50}+N_{>50}}
$$

where $N_{0-50}$ and $N_{>50}$ are the average abundance in the surface layer $(0-50 \mathrm{~m})$ and below $50 \mathrm{~m}$, respectively. $V$ takes values from -1 , when all organisms are present below $50 \mathrm{~m}$, to 1, when all organisms are present in 0-50 m. Due to variable abundances and many dates with low or no counts in several groups, we limited this analysis to the 9 most abundant zooplankton taxa or groups.

\section{RESULTS}

\section{Hydrography}

Near-shore (Stn 1), the relatively shallow water column remained mixed with salinity $<34.5$ and temperature $<10^{\circ} \mathrm{C}$ throughout most of the study period (Fig. 2A). In summer 2014, a relatively weak stratification established, and fluorescence levels increased near-surface. On the bank (Stn 2), a thermohaline vertical structure was retained throughout most of the year but was weakened in late winter and early spring (Fig. 2B). In autumn 2013 and summer 2014, surface waters reached $>10^{\circ} \mathrm{C}$, and salinity $>34.5$. Fluorescence values were low in winter and peaked in surface waters in late spring 2014. On the shelf slope (Stn 3), relatively high salinity (>35.0) and temperatures around $8^{\circ} \mathrm{C}$ dominated below $100 \mathrm{~m}$ throughout most of the study period (Fig. 2C). In the trough stations (Stns 4 and 5), deep-water salinity was somewhat lower than on the slope. Both trough stations were characterized by episodic drops in water-column salinity (in July in Stn 4 and in late May in Stn 5; Fig. 2D,E). Temperatures below ca. 100m were higher in autumn 2013, but lower in the trough than on the shelf slope during the remainder of the study period. Near-surface temperature and salinity in all the deeper stations (Stns 3-5) resembled that on the bank (Stn 2), with more or less simultaneous surface fluorescence peaks occurring in spring and summer 2014.

Modelled velocity fields indicated that currents were generally stronger in spring (March) than in summer (August, Fig. 3). The location of the NAC along the continental slope was similar during the 2 seasons, but more on-shelf inflow occurred in March, especially downstream of the sampling area (Fig. 3A). The direction and strength of the main currents remained relatively stable in spring but varied more in summer, with relatively frequent changes in current direction both onto and off the shelf that tended to slow down the northward transport (Fig. 3B).

\section{Abundance of dominant zooplankton}

A total of 17 taxa or groups of zooplankton occurred regularly in the samples (Fig. 4). In addition, a 


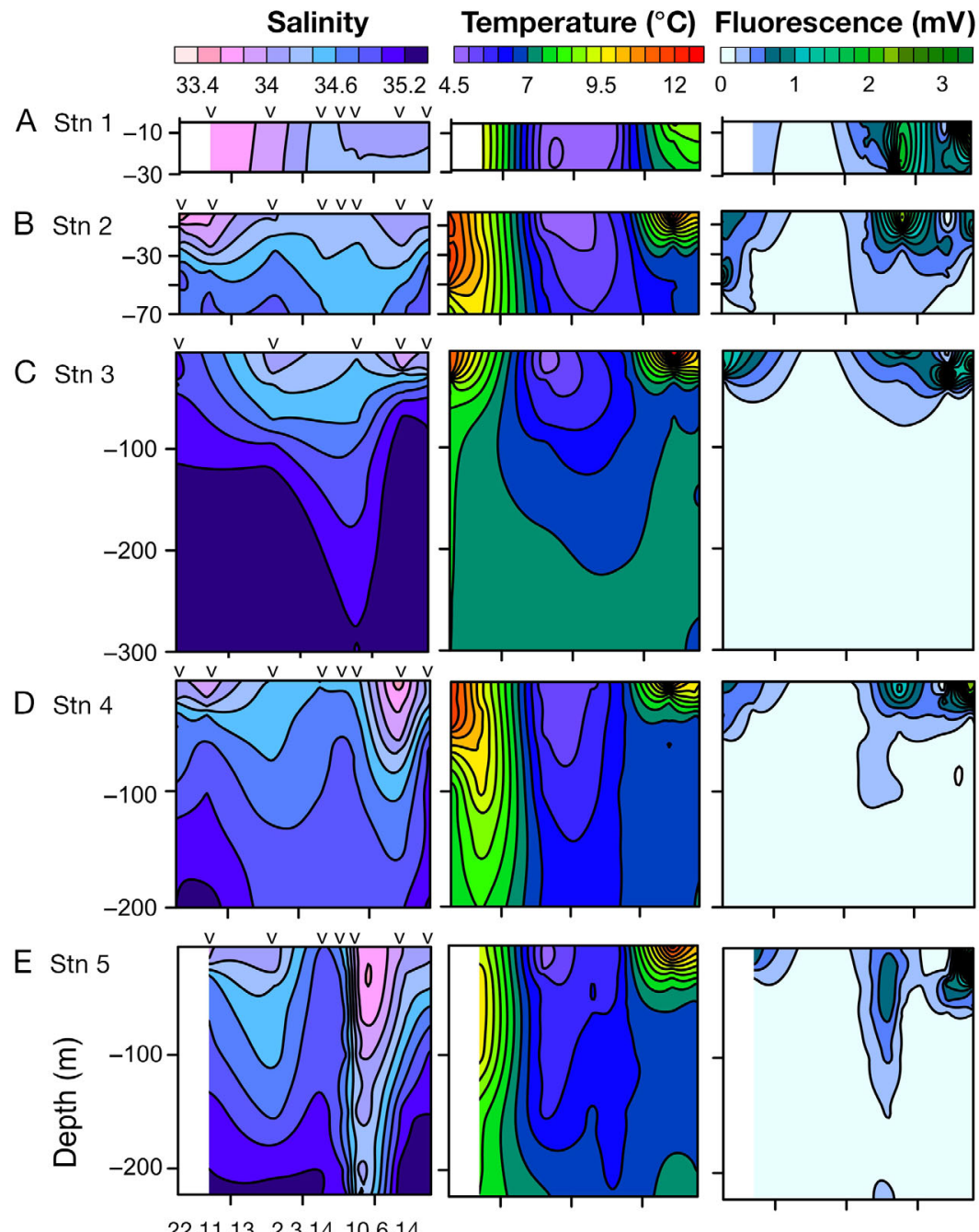

22.11.13 2.3.14 10.6 .14

Fig. 2. Interpolated salinity, temperature, and fluorescence levels at (A-E) the 5 sampling stations during the study period (September 2013-August 2014). Note that the number of sampling dates, indicated by $\vee$ on top of salinity panels for each station, varied between stations relatively small number $(<1 \%$ of total abundance) of specimens consisted of a diverse assemblage of mostly unidentified organisms. As the taxonomic affinity in this group varied, we have only distinguished between the copepod ('other copepods') and the non-copepod fractions ('other') when reporting abundances.

The 5 most abundant zooplankton groups accounted for $>90 \%$ of total numerical abundance (Table 2). These groups were (average abundance, ind. $\mathrm{m}^{-2}$ ) Calanus finmarchicus (103 108), Oithona similis (23 235), Limacina helicina (10905), Microcalanus sp. (7458), and nauplii (5429). In addition, Oikopleura dioica, Metridia longa, L. retroversa, and Pseudocalanus sp. were relatively abundant (average abundance $>1000$ ind. $\mathrm{m}^{-2}$, Fig. 4). In combination, these 9 groups accounted for $98.7 \%$ of the total counts during this investigation.

Abundance estimates of the identified groups or taxa varied relatively little between individual stations, but some differences were noticeable. Overall, the abundance differed between stations in M. longa, Microcalanus sp., Triconia borealis, and chaetognaths (Kruskal-Wallis rank tests, $\mathrm{df}=4$; Table 3 ). In these cases, the averaged abundance was lower near the coast (Stn 1), and, for $T$. borealis and chaetognaths (mainly Sagitta elegans and Eukrohnia hamata), on the bank (Stn 2), as well.
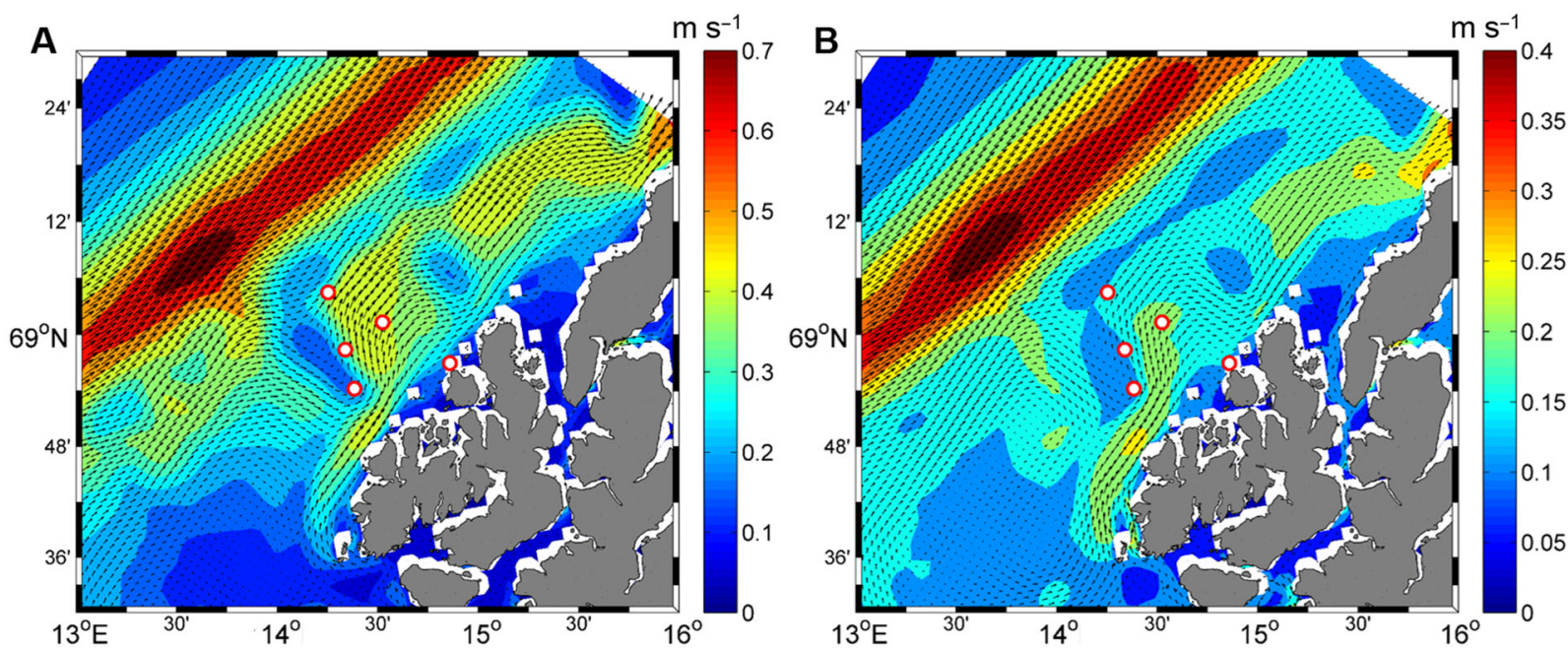

Fig. 3. Average circulation conditions based on modelled velocity field for (A) March and (B) August 2014. The arrows show the monthly mean direction of the current, and the color bar indicates the monthly mean velocity 
A Hydrozoa indet.
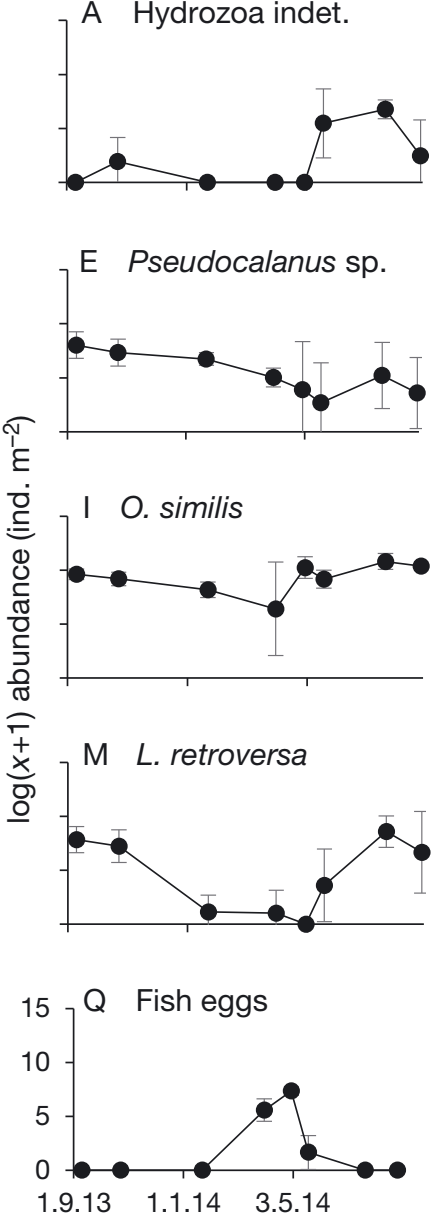

Fig. 4. Temporal variability in $\log (x+1)$-transformed abundance of the most common taxa and groups in the study area on 8 sampling dates from September 2013 to August 2014 (see Tables $1 \& 2$ for details). On each of the 8 sampling dates, abundance was averaged over all stations sampled. Bars denote $\pm 1 \mathrm{SD}$
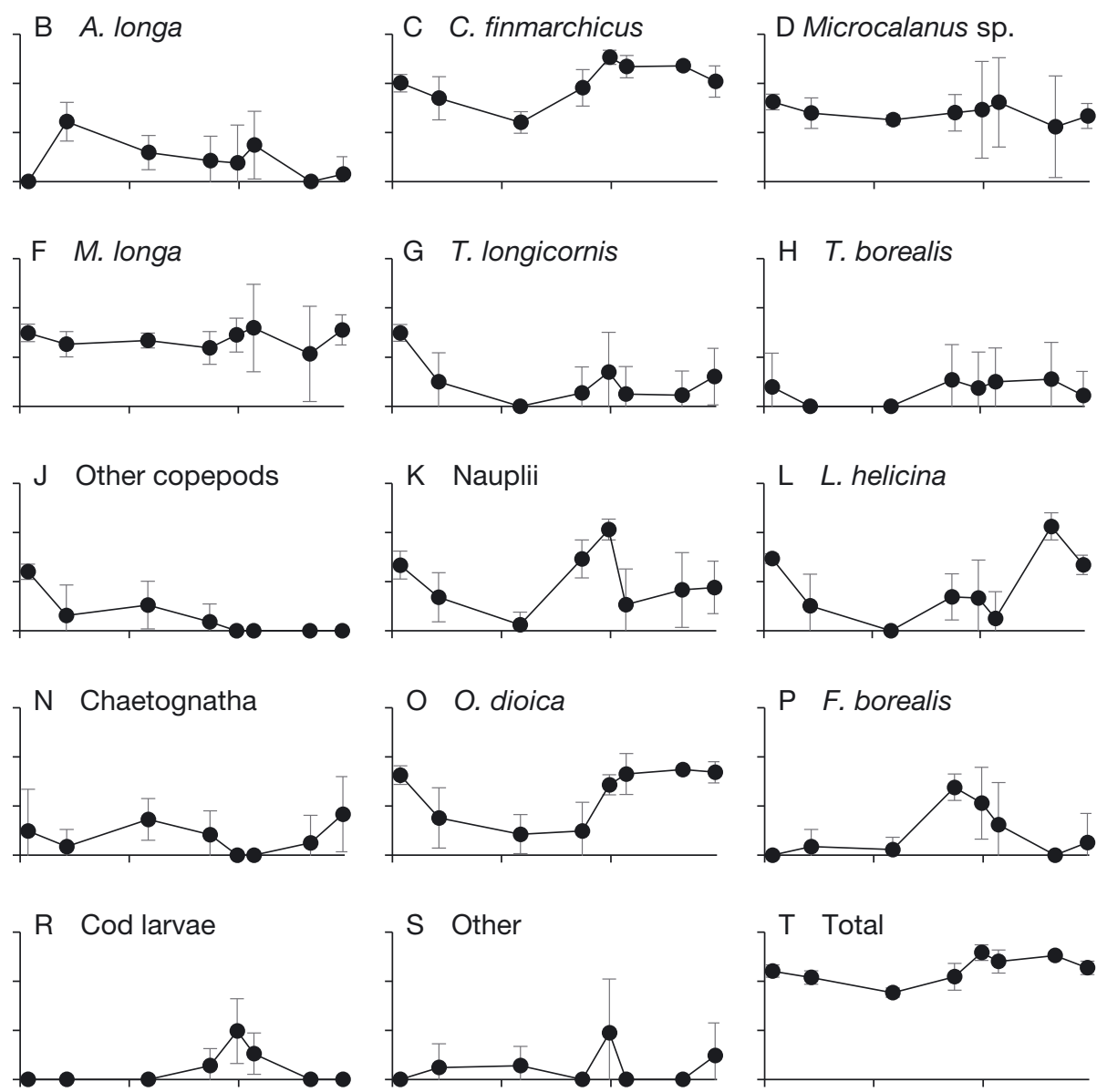

Sampling date
Although not statistically significant, we also note that abundances were also relatively low in Temora longicornis in the near-shore station (Stn 1) and in the inner trough (Stn 5), and that abundance of $L$. helicina, Fritillaria borealis, and the ichtyoplankton were low on the shelf slope (Stn 3). The abundance of Acartia longiremis was lowest in the outer trough (Stn 4). Similarly, the average concentrations of nauplii were relatively high on the bank (Stn 2) and in the trough station (Stn 4), while chaetognaths were relatively more abundant on the shelf slope and in the trough.

\section{Temporal variability in the abundance of the dominant zooplankton}

C. finmarchicus and the unidentified nauplii peaked in abundance in early May 2014 (Fig. 4). Both
Limacina species and $O$. dioica were abundant in September 2013 and in July and August 2014 (May-August for O. dioica), but were only encountered in low densities at other times. Abundance estimates for Pseudocalanus sp., T. longicornis, and the unidentified copepods decreased from the first sampling in September 2013. Ichtyoplankton and F. borealis were abundant in spring (April and May), but otherwise contributed little to the total net caught zooplankton. The abundances of Microcalanus sp., M. longa, $O$. similis, and total zooplankton, varied relatively little between sampling dates (Fig. 4).

\section{Vertical distribution in the deep stations}

At the 3 deepest stations (Stns $3-5$ ), $>50 \%$ of copepodites of $C$. finmarchicus remained in the upper 50 m in September 2013 and from April-July in 2014 


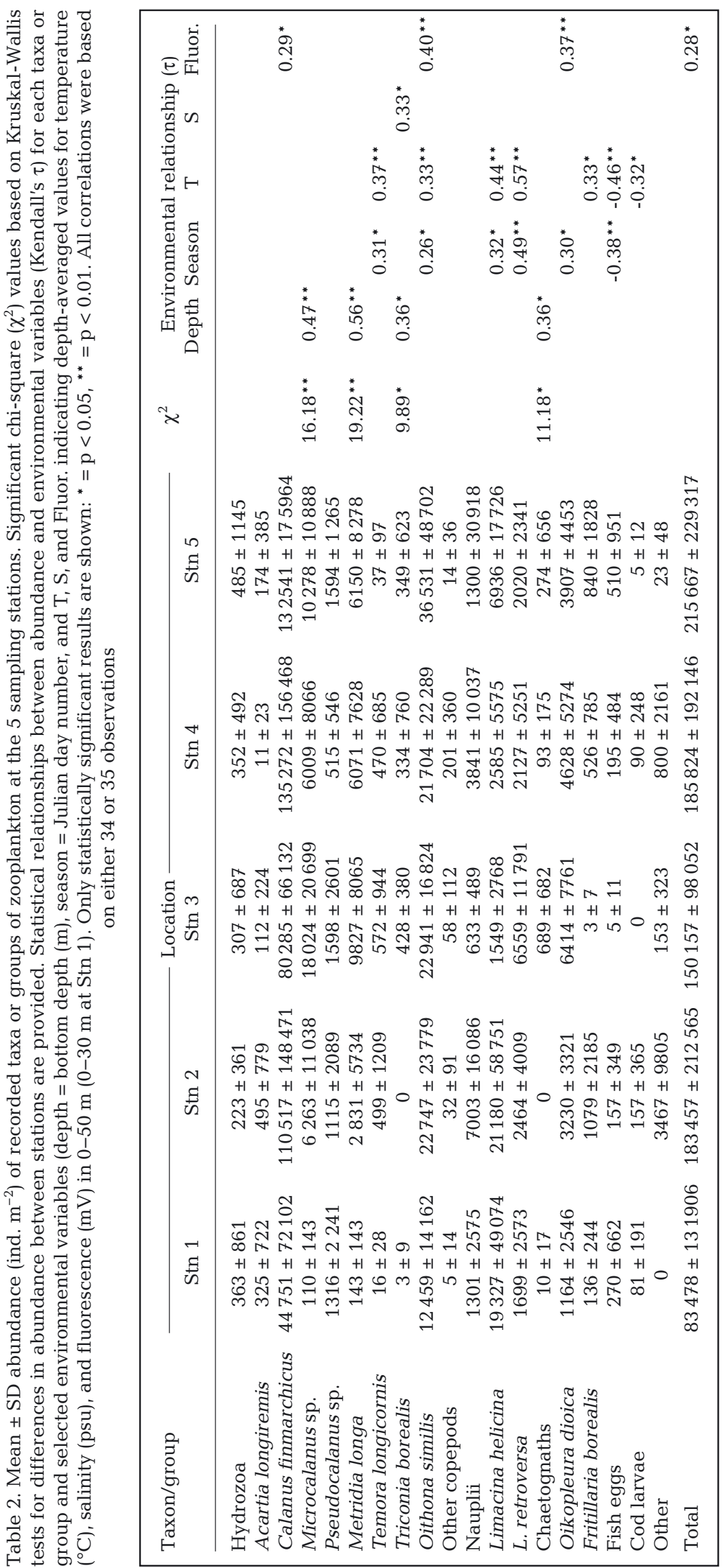

(Fig. 5). Microcalanus sp., O. dioica, and $M$. longa were mainly distributed below $50 \mathrm{~m}$ throughout the study period, while Pseudocalanus sp. remained dispersed throughout the water column, and $O$. similis abundance was highest in the upper $50 \mathrm{~m}$. For both Limacina spp., the data coverage was poorer (i.e. abundances were very low in winter and early spring; Fig. 4). The available data indicates that the bulk of both populations were present in the upper $50 \mathrm{~m}$ in early autumn 2013, descended into deeper waters in late autumn, and were found closer to surface again from late spring 2014 (Fig. 5 C,H). The nauplii were also largely located close to surface in autumn and summer but deeper in winter and spring (Fig. 5E).

\section{Environmental variability and zooplankton abundance}

Models of aggregated abundances indicated that 4 taxa were related to the season factor and 3 taxa varied with the depth factor (Table 3). C. finmarchicus and total zooplankton abundance varied significantly with both factors. Significant interaction effects between the 2 factors did not occur in any of the taxa or groups. Note that for $M$. longa and both Limacina spp. residuals deviated more from normality (Shapiro-Wilk test: $0.05>p>0.01$ ) than in the other taxa or groups $(p>0.05)$. For 7 of the identified zooplankton groups, abundance correlated with temperature (Table 2). For 5 of these (T. longicornis, O. similis, both Limacina spp. and F. borealis), the association was positive, while fish eggs and cod larvae correlated inversely with temperature. T. borealis correlated with salinity, while C. finmarchicus, O. similis, and $O$. dioica correlated positively with fluorescence. Abundance of $T$. longicornis, $O$. similis, both Limacina spp., $O$. dioica, and fish eggs correlated with the day of year of sampling. 

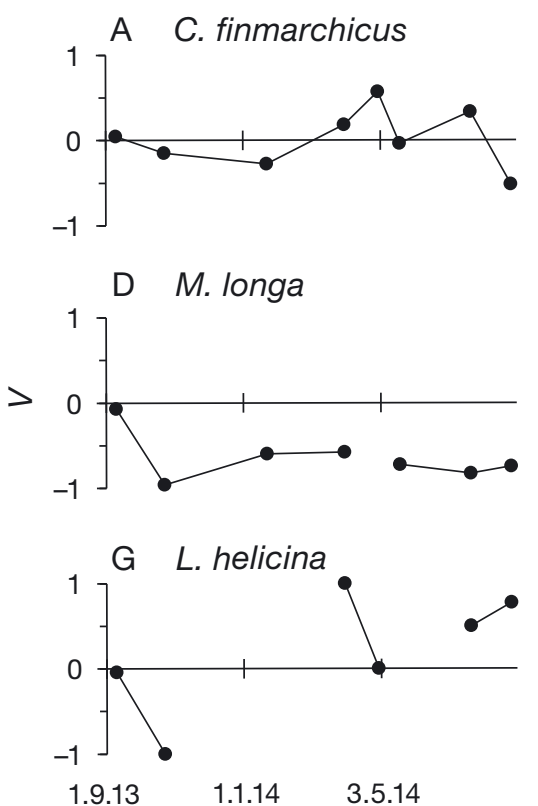

B Microcalanus sp.

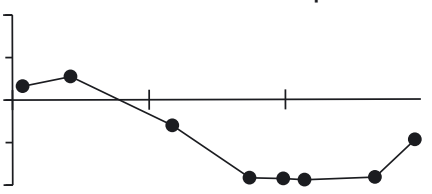

E O. similis
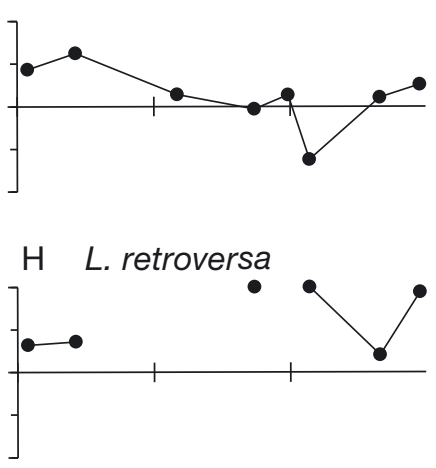

Sampling date
C Pseudocalanus sp.
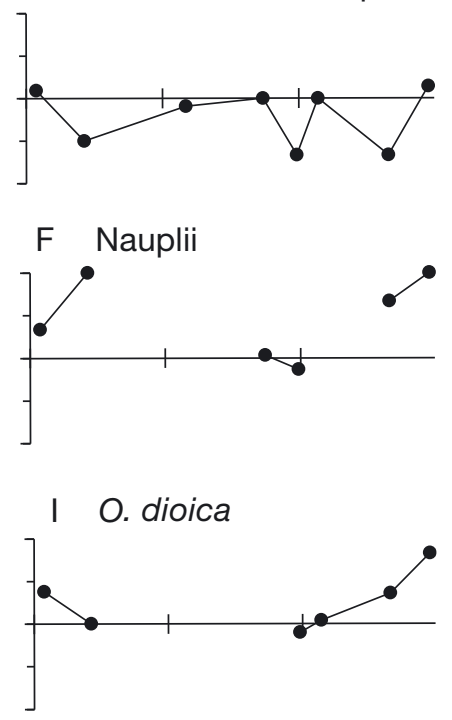

Fig. 5. Variability in the vertical distribution index ( $V$ ) of (A-I) the 9 most abundant zooplankton taxa or groups (see Table 2 for full genus names) at the 3 deepest stations (Stns 3-5) during the investigation. $V=1$ indicates the entire population was present in the surface layer $(0-50 \mathrm{~m})$ and $V=-1$ indicates population is located below $50 \mathrm{~m}$. Note that, due to low and variable abundances, $V$ could not be estimated for all groups on each sampling day

Note, however, that temperature and day-of-year of sampling were correlated (Kendall's $\tau=0.76, \mathrm{p}<$ $0.001, \mathrm{df}=33$ ). Abundances of Microcalanus sp., $M$. longa, T. borealis, and chaetognaths correlated positively with bottom depth (Table 2).

Table 3. The relationships between abundance and lumped categories of 2 independent variables, season: a 3 -factor variable of seasonally lumped data based on sampling period: autumn $=$ September and October in 2013, winter $=$ January and April in 2014, and summer = May through August in 2014, and depth: a 2-factor lumped representation of bottom depth where relatively shallow locations $(\leq 75 \mathrm{~m}$ bottom depth) are Stns 1 and 2, and deep locations ( $\geq 200 \mathrm{~m}$ ) are Stns 3-5). Models are either 1-way or 2-way ANOVA. Reported values are F-values (sum of squares) with significance level for each factor, depth $(\mathrm{df}=1)$ and season $(\mathrm{df}=2)$. Only significant relationships with reasonably well-behaved residuals are shown: ${ }^{*}=\mathrm{p}<0.05,{ }^{* *}=\mathrm{p}<0.01$

\begin{tabular}{|lcc|}
\hline Taxon & Season & Depth \\
\hline Calanus finmarchicus & $19.6(101.2)^{* *}$ & $5.8(15.1)^{* *}$ \\
Microcalanus sp. & & $13.2(88.6)^{* *}$ \\
Metridia longa & & $18.7(85.9)^{* *}$ \\
Limacina helicina & $3.6(101.1)^{*}$ & \\
L. retroversa & $8.2(171.1)^{* *}$ & \\
Oikopleura dioica & $25.6(216.1)^{* *}$ & \\
Total & $25.8(44.6)^{* *}$ & $5.1(4.4)^{*}$ \\
\hline
\end{tabular}

\section{DISCUSSION}

Our results suggest that variability in shelf zooplankton abundance off the Lofoten islands tends to reflect either time of sampling or location. Overall, the effects of aggregated depth and season factors (Table 3) were fewer, but appeared similar to that indicated by correlations of non-aggregated data (Table 2). This was mainly due to a number of effects in taxa or groups for which deviations from normality in residuals were very high (mainly caused by many zero counts), and thus was not reported in Table 3. However, the aggregated analysis points to possible effects of both topography and seasonality in both Calanus finmarchicus and in total zooplankton; this effect was not indicated in the analysis based on nonaggregated data, where there was a relationship with fluorescence, only (Table 2).

In half of the zooplankton taxa or groups investigated, abundance correlated with day-of-year and seasonal environmental variability (water temperature or fluorescence), but did not vary systematically between locations (Table 2). These taxa or groups included several consumers on low trophic levels such as copepods, pteropods, and larvaceans. The relationships were always stronger (i.e. higher $\tau$ ) with either temperature or fluorescence, both sea- 
sonally varying in the study area (Fig. 2), than with day of year. We interpret this as indicating that abundance primarily reflected underlying physiological or ecological responses to recurring patterns in environmental variability. This was probably largely mediated by numerical, behavioural, or life-history responses to seasonality in food availability and predation risk (Herman 1983, Conover \& Huntley, 1991, Søreide et al. 2010, Varpe 2012). As most plankton are short-lived, their abundances tend to respond quickly to such environmental changes (Hays et al. 2005).

In four $(20 \%)$ of the investigated groups or taxa, abundance differed between sampling location, and showed little signs of relationship with sampling date. We interpret this as likely reflecting taxaspecific affinities for location, which is probably related to preferences for relatively deep habitats as suggested by the association between abundance and bottom depth in these groups in the present study (Table 2). These taxa (Metridia longa, Microcalanus sp., Triconia borealis, and the chaetognaths) are typically characterized as either carnivores, omnivores, or detritivores (e.g. Haq 1967, Kattner et al. 2003, Michels \& Schnack-Schiel 2005), that tend to be distributed relatively deep in the water column (Ashjian et al. 2003, Darnis \& Fortier 2014). Thus, their depth distribution likely limited dispersion onto the shallow bank and into the shallow near-shore waters. This view is supported by the mostly deep vertical distribution of Microcalanus sp. and M. longa in this study (Fig. 5), but could not be ascertained for T. borealis and the chaetognaths due to low and variable abundances in these taxa (Fig. 4). However, $T$. borealis is mainly distributed below the halocline at ca. $200 \mathrm{~m}$ (Darnis \& Fortier 2014) and chaetognaths tend to distribute relatively deep in the water column (Grigor et al. 2014). Zooplankton with preferences for deep habitats suggest a life-cycle where the trophic position, and likely also the timing of reproduction, are not closely linked to the near-surface and highly seasonal primary productivity (Bandara et al. 2016). This may explain the relatively low temporal abundance variability of these taxa during the present study (Fig. 4). Thus, abundance differences between stations in these taxa were likely due to the limited extent to which they occupied the surface layer and, therefore, restricted transport into shallow areas on the shelf.

The relationship between the aggregated abundances of $C$. finmarchicus and bottom depth (Table 3) reflected a negative effect in shallow stations (effect $\pm \mathrm{SE}=-1.33 \pm 0.55, \mathrm{p}=0.02)$ and is in line with rela- tionships between C. finmarchicus and bathymetry found elsewhere (Daase et al. 2007). For total zooplankton, the effect of bottom depth (Table 3) was probably caused by the relatively high contribution from $C$. finmarchicus, the dominant species in this investigation (Table 2). The minimal adequate ANOVA model (not shown) for total zooplanktonC. finmarchicus did not indicate depth as a significant factor.

In the remaining taxa or groups, no association was established with either bottom depth or season (Tables 2 \& 3). Pseudocalanus sp. abundance varied relatively little throughout the study, both between stations and over time (Table 2, Fig. 4), and it seemed to be distributed throughout much of the water column (Fig. 5). Pseudocalanus is believed to remain active throughout all seasons as they are not capable of storing sufficient lipid reserves to successfully hibernate (Lischka \& Hagen 2007), but their trophic affinity in winter remains unclear (Darnis \& Fortier 2014). However, as several of these groups likely contained multiple species with different phenology, the lack of seasonality in abundance could be explained by different population dynamics of the constituents dampening out signals for the entire group.

In Acartia. longiremis, abundance peaks in May to

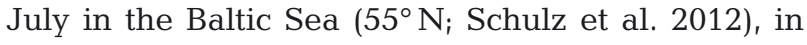

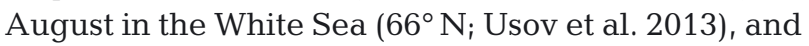
in November in Svalbard coastal waters $\left(79^{\circ} \mathrm{N}\right.$; Lischka \& Hagen 2016). Differences in the timing of the A. longiremis peak in these locations suggest that this widely distributed neritic species adjusts its phenology to the prevailing local environmental conditions (e.g. temperature, phytoplankton bloom, predator field etc.). Thus our recorded A. longiremis abundances may reflect a mixture of local and advected populations in varying phases of its development. This may have weakened any underlying association with local environment or date of sampling.

The volume transport in the dominant current system of the study area tends to slow down and stabilize in spring and summer, primarily due to seasonality in wind regime and freshwater influence (Skagseth et al. 2011). Although inshore Ekman transport in spring varies substantially between years, the study area is mainly fed by waters originating from coastal sources south of the study area and only to a limited degree from the oceanic region (Espinasse et al. 2017; Fig. 3). Thus, the fauna in the study area may reflect influxes of biota advected from coastal areas south of the study area in addition to more local populations. The main hydrographic difference in the study area was the presence of relatively high 
saline waters, most likely of Atlantic origin, in the deeper parts on the shelf break and on the 2 trough stations (Fig. 2). Lower salinity waters prevailed near the coast and on the bank. On at least 2 occasions (in July in Stn 4, and in May in Stn 5), the shelf also received pulses of relatively low-salinity water that may have been associated with significant advection of zooplankton from upstream shelf source populations. If such source populations were in different phases of population development, this advection could have contributed to dampening any local abundance trend with season or space in our data set.

Our data derived from sampling with relatively coarse-meshed plankton nets and because of limited ship availability and unfavourable weather conditions resulted in uneven timing of sampling events. The relatively coarse nets used may have led to a bias in abundance estimates of some of the smaller taxa, and, most notably, may have led to an underestimation of abundance of their younger, and smaller, developmental stages (e.g. Ashjian et al. 2003, Darnis \& Fortier 2014). Similarly, the uneven sampling dates, and especially the gap of 2 months in our data set in summer (Table 1), may have limited the possibility of detecting relevant abundance variability in some species. Zooplankton abundances recorded in the present study, however, fall within the range of what is reported from shelves and coastal areas elsewhere (e.g. Walkusz et al. 2009, Dvoretsky \& Dvoretsky 2015, Buttay et al. 2016, Stübner et al. 2016), thus we are reasonably sure that our data are representative of the most common zooplankton groups on the shelf.

In conclusion, our results shed some light on the contextualization of shelf zooplankton, and thus community composition, in relation to spatial mesoscale bathymetry and with seasonal environmental variability on the northern Norwegian shelf. This information may prove useful in the design of field studies and provide a base-line for validation of spatially resolved biological models (e.g. Espinasse et al. 2017). We suggest the observed mesoscale patterns in abundance of important zooplankton species mainly reflected general ecological differences in numerical responses to environmental swings and in vertical habitat choice that seems to exist between the mainly herbivorous and omnivorous or carnivorous species (Bandara et al. 2016). For zooplankton that tend to avoid surface waters, the bottom topography on the shelf may effectively have limited their dispersion into relatively shallow near-shore and bank waters. Our results, therefore, support the view that in the complex hydrography found on many shelves, zoo- plankton vertical behaviour and bathymetry may contribute significantly to sustain mesoscale community variability (Barange 1994, Genin 2004), even in highly advective scenarios as the one studied here.

These findings underline the spatiotemporal complexity in the distribution of shelf zooplankton (PinelAlloul 1995, Folt \& Burns 1999). Such complexity is likely ecologically important as it may carry over into the organization of higher trophic levels (Buttay et al. 2016, Suchy et al. 2016). Larval and juvenile cod, for instance, are important components of the northern Norwegian shelf ecosystem in early spring and summer (Ottersen et al. 2014). They tend to distribute in relation to spatial heterogeneity in the distribution of their prey or that of favourable hydrography (Skreslet 1989, Helle \& Pennington 1999). In our study, a similar mechanism, presumably leading to passive aggregations of zooplankton, possibly caused by local up- or down-welling or the formation of mesoscale eddies, was reflected in the correlation between abundance and surface layer hydrography in half of the taxonomic groups studied (Table 2). This indicates that further studies of plankton ecology may do well to incorporate the effects of spatial mesoscale heterogeneity in studies of biodiversity, trophic interactions, and secondary production on shelves and in coastal waters with complex bathymetry.

Acknowledgements. We thank the captains and crews of F/Vs 'Kloegga', 'Mea', 'Brutus', and 'Skårungen' for valuable assistance during field collections. The authors thank 2 anonymous referees for their valuable contributions to the final version of the manuscript. This study is a contribution of the ARCTOS LoVe MarinEco project, made possible through the support of Statoil.

\section{LITERATURE CITED}

Albretsen J, Sperrevik A, Staalstrøm A, Sandvik AD, Vikebø FB, Asplin L (2011) NorKyst-800 Report No.1. User manual and technical descriptions. Tech Rep Fisken Havet 2/2011, Institute of Marine Research, Bergen

Arashkevich E, Wassmann P, Pasternak A, Wexels Riser C (2002) Seasonal and spatial changes in biomass, structure, and development progress of the zooplankton community in the Barents Sea. J Mar Syst 38:125-145

* Ashjian CJ, Campbell RG, Welch HE, Butler M, Van Keuren D (2003) Annual cycle in abundance, distribution, and size in relation to hydrography of important copepod species in the western Arctic Ocean. Deep Sea Res I 50:1235-1261

Astthorsson OS, Gislason A (2003) Seasonal variations in abundance, development and vertical distribution of Calanus finmarchicus, C. hyperboreus and C. glacialis in the East Icelandic Current. J Plankton Res 25:843-854

* Bagøien E, Kaartvedt S, Aksnes DL, Eiane K (2001) Vertical distribution and mortality of overwintering Calanus. Limnol Oceanogr 46:1494-1510 
Bandara K, Varpe Ø, Søreide JE, Wallenschus J, Berge J, Eiane K (2016) Seasonal vertical strategies in a highArctic coastal zooplankton community. Mar Ecol Prog Ser 555:49-64

Bandara K, Varpe Ø, Ji R, Eiane K (2018) A high-resolution modeling study on diel and seasonal vertical migrations of high-latitude copepods. Ecol Modell 368:357-376

Banse K (1995) Zooplankton: pivotal role in the control of ocean production: I. Biomass and production. ICES J Mar Sci 52:265-277

Barange M (1994) Acoustic identification, classification and structure of biological patchiness of the edge of the Agulhas Bank and its relation to frontal features. S Afr J Mar Sci 14:333-347

Beaugrand G (2012) Unanticipated biological changes and global warming. Mar Ecol Prog Ser 445:293-301

* Brander KM, Dickson RR, Shepherd JG (2001) Modelling the timing of plankton production and its effect on recruitment of cod (Gadus morhua). ICES J Mar Sci 58: 962-966

Buttay L, Miranda A, Casas G, González-Quirós R, Nogueira E (2016) Long-term and seasonal zooplankton dynamics in the northwest Iberian shelf and its relationship with meteo-climatic and hydrographic variability. J Plankton Res 38:106-121

Chiba S, Saino T (2003) Variation in mesozooplankton community structure in the Japan/East Sea (1991-1999) with possible influence of the ENSO scale climatic variability. Prog Oceanogr 57:317-339

Conover RJ, Huntley M (1991) Copepods in ice-covered seas - distribution, adaptations to seasonally limited food, metabolism, growth patterns and life cycle strategies in polar seas. J Mar Syst 2:1-41

Daase M, Eiane K (2007) Mesozooplankton distribution in northern Svalbard waters in relation to hydrography. Polar Biol 30:969-981

* Daase M, Vik JO, Bagøien E, Stenseth NC, Eiane K (2007) The impact of advection on Calanus near Svalbard: statistical relations between salinity, temperature and copepod abundance. J Plankton Res 29:903-911

Dalpadado P (2006) Distribution and reproduction strategies of krill (Euphausiacea) on the Norwegian shelf. Polar Biol 29:849-859

Darnis G, Fortier L (2014) Temperature, food and the seasonal vertical migration of key Arctic copepods in the thermally stratified Amundsen Gulf (Beaufort Sea, Arctic Ocean). J Plankton Res 36:1092-1108

* Dvoretsky VG, Dvoretsky AG (2015) Regional differences of mesozooplankton communities in the Kara Sea. Cont Shelf Res 105:26-41

Eiane K, Aksnes DL, Ohman MD, Wood S, Martinussen MB (2002) Stage specific mortality of Calanus spp. under different predation regimes. Limnol Oceanogr 47:636-645

Espinasse B, Tverberg V, Basedow S, Hattermann T and others (2017) Mechanisms regulating inter-annual variability in zooplankton advection over the Lofoten shelf, implications for cod larvae survival. Fish Oceanogr 26: 299-315

Falk-Petersen S, Hagen W, Kattner W, Clarke A, Sargent J (2000) Lipids, trophic relationships, and biodiversity in Arctic and Antarctic krill. Can J Fish Aquat Sci 57: 178-191

Folt CL, Burns CW (1999) Biological drivers of zooplankton patchiness. Trends Ecol Evol 14:300-305

Fromentin JM, Planque B (1996) Calanus and environment in the eastern North Atlantic. 2. Influence of the North Atlantic Oscillation on C. finmarchicus and C. helgolandicus. Mar Ecol Prog Ser 134:111-118

* Gascard JC, Raisbeck G, Sequeira S, Yiou F, Mork KA (2004) The Norwegian Atlantic Current in the Lofoten basin inferred from hydrological and tracer data (129I) and its interaction with the Norwegian Coastal Current. Geophys Res Lett 31:L01308

Genin A (2004) Bio-physical coupling in the formation of zooplankton and fish aggregations over abrupt topographies. J Mar Syst 50:3-20

* Grigor JJ, Søreide JE, Varpe Ø (2014) Seasonal ecology and life-history strategy of the high-latitude predatory zooplankter Parasagitta elegans. Mar Ecol Prog Ser 499: 77-88

Haidvogel DB, Arango H, Budgell WP, Cornuelle BD and others (2008) Ocean forecasting in terrain-following coordinates: formulation and skill assessment of the Regional Ocean Modeling System. J Comput Phys 227: 3595-3624

*Haq SM (1967) Nutritional physiology of Metridia lucens and $M$. longa from the Gulf of Maine. Limnol Oceanogr 12:40-51

*Hays GC, Richardson AJ, Robinson C (2005) Climate change and marine plankton. Trends Ecol Evol 20: 337-344

Helle K, Pennington M (1999) The relation of the spatial distribution of early juvenile cod (Gadus morhua L.) in the Barents Sea to zooplankton density and water flux during the period 1978-1984. ICES J Mar Sci 56:15-27

*Herman AW (1983) Vertical distribution patterns of copepods, chlorophyll, and production in northeastern Baffin Bay. Limnol Oceanogr 28:709-719

*Hirche HJ, Brey T, Niehoff B (2001) A high-frequency time series at Ocean Weather Ship Station M (Norwegian Sea): population dynamics of Calanus finmarchicus. Mar Ecol Prog Ser 219:205-219

Kattner G, Albers C, Graeve M, Schnack-Schiel SB (2003) Fatty acid and alcohol composition of the small polar copepods Oithona and Oncaea: indication of feeding modes. Polar Biol 26:666-671

KLischka S, Hagen W (2007) Seasonal lipid dynamics of the copepods Pseudocalanus minutus (Calanoida) and Oithona similis (Cyclopoida) in the Arctic Kongsfjorden (Svalbard). Mar Biol 150:443-454

*Lischka S, Hagen W (2016) Seasonal dynamics of mesozooplankton in the Arctic Kongsfjord (Svalbard) during year-round observations from August 1998 to July 1999. Polar Biol 39:1859-1878

* Macquart-Moulin C, Patriti G (1996) Accumulation of migratory micronekton crustaceans over the upper slope and submarine canyons of the northwestern Mediterranean. Deep-Sea Res 43:579-601

Michels J, Schnack-Schiel SB (2005) Feeding in dominant Antarctic copepods-Does the morphology of the mandibular gnatobases relate to diet? Mar Biol 146: 483-495

Mitchelson-Jacob G, Sundby S (2001) Eddies of Vestfjorden, Norway. Cont Shelf Res 21:1901-1918

Motoda S (1985) Devices of Simple Plankton ApparatusVII. Bull Mar Sci 37:776-777

Munk P, Nielsen TG, Hansen BW (2015) Horizontal and vertical dynamics of zooplankton and larval fish communities during mid-summer in Disko Bay, West Greenland. J Plankton Res 37:554-570 
Myksvoll MS, Jung KM, Albretsen J, Sundby S (2014) Modelling dispersal of eggs and quantifying connectivity among Norwegian coastal cod subpopulations. ICES J Mar Sci 71:957-969

Ohman MD, Hsieh CH (2008) Spatial differences in mortality of Calanus pacificus within the California Current System. J Plankton Res 30:359-366

* Opdal AF, Vikebø FB (2016) Long-term stability in modelled zooplankton influx could uphold major fish spawning grounds on the Norwegian continental shelf. Can J Fish Aquat Sci 73:189-196

Østvedt OJ (1955) Zooplankton investigations from weathership 'M' in the Norwegian Sea, 1948-49. Hvalråd Skr 40: $1-93$

Ottersen G, Bogstad B, Yaragina NA, Stige LC, Vikebø FB, Dalpadado $P$ (2014) A review of early life history dynamics of Barents Sea cod (Gadus morhua). ICES J Mar Sci 71:2064-2087

Pinel-Alloul B (1995) Spatial heterogeneity as a multiscale characteristic of zooplankton community. Hydrobiologia $300: 17-42$

Richardson AJ, Schoeman DS (2004) Climate impact on plankton ecosystems in the Northeast Atlantic. Science 305:1609-1612

Sætre R (1999) Features of the central Norwegian shelf circulation. Cont Shelf Res 19:1809-1831

* Samuelsen A, Huse G, Hansen C (2009) Shelf recruitment of Calanus finmarchicus off the west coast of Norway: role of physical processes and timing of diapause termination. Mar Ecol Prog Ser 386:163-180

Schulz J, Peck MA, Barz K, Schmidt JO and others (2012) Spatial and temporal habitat partitioning by zooplankton in the Bornholm Basin (central Baltic Sea). Prog Oceanogr 107:3-30

Shchepetkin AF, McWilliams JC (2005) The regional oceanic modeling system (ROMS): a split-explicit, freesurface, topography-following-coordinate oceanic model. Ocean Model 9:347-404

Silberberger MJ, Renaud PE, Espinasse B, Reiss H (2016) Spatial and temporal structure of the meroplankton community in a sub-Arctic shelf system. Mar Ecol Prog Ser 555:79-93

Skagseth Ø, Drinkwater KF, Terrile E (2011) Wind- and buoyancy-induced transport of the Norwegian Coastal Current in the Barents Sea. J Geophys Res 116:C08007

Skarðhamar J, Skagseth Ø, Albretsen J (2015) Diurnal tides on the Barents Sea continental slope. Deep Sea Res I 97: $40-51$

Skreslet S (1989) Spatial match and mismatch between larvae of cod (Gadus morhua L.) and their principal prey, nauplii of Calanus finmarchicus (Gunnerus). Rapp P-V Reùn Cons Int Explor Mer 191:258-263

Skreslet S, Olsen K, Chelak M, Eiane K (2015) NE Atlantic

Editorial responsibility: Wen-Xiong Wang,

Kowloon, Hong Kong, SAR zooplankton wintering in fjord habitats respond to hemispheric climate. J Plankton Res 37:773-789

Slagstad D, Tande KS (2007) Structure and resilience of overwintering habitats of Calanus finmarchicus in the Eastern Norwegian Sea. Deep Sea Res II 54:2702-2715

Søreide JE, Leu E, Berge J, Graeve M, Falk-Petersen S (2010) Timing of blooms, algal food quality and Calanus glacialis reproduction and growth in a changing Arctic. Glob Change Biol 16:3154-3163

Stübner EI, Søreide JE, Reigstad M, Marquardt M, Blachowiak-Samolyk K (2016) Year-round meroplankton dynamics in high-Arctic Svalbard. J Plankton Res 38:522-536

Suchy KD, Dower JF, Varela DE, Lagunas MG (2016) Interannual variability in the relationship between in situ primary productivity and somatic crustacean productivity in a temperate fjord. Mar Ecol Prog Ser 545:91-108

Sundby S (2000) Recruitment of Atlantic cod stocks in relation to temperature and advection of copepod populations. Sarsia 85:277-298

Tiku ML (1971) Power function of the F-test under nonnormal situations. J Am Stat Assoc 66:913-916

* Tremblay MJ, Roff JC (1983) Community gradients in the Scotian-shelf zooplankton. Can J Fish Aquat Sci 40: 598-611

Usov N, Kutcheva I, Primakov I, Martynova D (2013) Every species is good in its season: Do the shifts in the annual temperature dynamics affect the phenology of the zooplankton species in the White Sea? Hydrobiologia 706: $11-33$

Varpe $\varnothing ~(2012)$ Fitness and phenology: annual routines and zooplankton adaptations to seasonal cycles. J Plankton Res 34:267-276

Vilar JMG, Solé RV, Rubi JM (2003) On the origin of plankton patchiness. Physica A 317:239-246

Vogedes D, Eiane K, Båtnes AS, Berge J (2014) Variability in Calanus spp. abundance on fine- to mesoscale in an Arctic fjord: implications for little auk feeding. Mar Biol Res 10:437-448

Walkusz W, Kwansiewski S, Falk-Petersen S, Hop H, Tverberg V, Wieczorek P, Weslawski JM (2009) Seasonal and spatial changes in the zooplankton community of Kongsfjorden, Svalbard. Polar Res 28:254-281

Willis KJ, Cottier FR, Kwaśniewski S (2008) Impact of warm water advection on the winter zooplankton community in an Arctic fjord. Polar Biol 31:475-481

Y Young KV, Dover JF, Pepin P (2009) A hierarchical analysis of the spatial distribution of larval fish prey. J Plankton Res 31:687-700

K Zhou M, Tande KS, Zhu Y, Basedow S (2009) Productivity, trophic levels and size spectra of zooplankton in northern Norwegian shelf regions. Deep Sea Res II 56: 1934-1944

Submitted: November 13, 2017; Accepted: May 29, 2018

Proofs received from author(s): July 19, 2018 